\title{
E-MONEY PERSPEKTIF MAQASHID SYARIAH FII AL-MUAMALAH
}

\author{
Sajida Sanata Islam, Iffatin Nur \\ Universitas Islam Negeri Sayyid Ali Rahmatullah Tulungagung \\ Email: sajidasanata@gmail.com dan iffaeltinury@gmail.com
}

\begin{abstract}
E-money is a modernization of technology-based non-cash payment methods that are currently commonly used by the public. The development of this e-money based payment method must of course be in line with religious principles. This study aims to determine whether the existence of e-money is in line with the maqashid syariah fi al-muamalah concept. The type of research used is normative legal research with a qualitative approach, the technique of collecting legal materials used is document study or literature study using qualitative descriptive methods. The results show that the law of transacting with e-money is permissible based on the principle of "Al ashlu fil mua'malati al ibahah hatta yadullu ad-daliilu ala tahrimiha", but this change is limited to e-money with sharia principles guided by the Fatwa Council. National Sharia. As for conventional e-money, it is considered that it does not comply with sharia principles, we should avoid its use because it is feared that there are elements of riba, gharar, and maitsir that can harm the parties in the e-money.
\end{abstract}

Keywords: E-Money, Maqashid Syariah Fi Al-Muamalah, Maslahah.

\begin{abstract}
Abstrak
E-money merupakan modernisasi metode pembayaran non tunai berbasis teknologi yang saat ini lazim digunakan oleh masyarakat. Perkembsngsn metode pembayaran berbaasi e-money ini tentunya harus sejalan dengan prinsip-prinsip agama. Penelitian ini bertujuan untuk mengetahui apakah dengan adanya e-money ini sejalan dengan kosep maqashid syariah fi almuamalah. Jenis penelitian yang digunakan adalah penelitian hukum normatif dengan pendekatan kualitatif, teknik pengumpulan bahan hukum yang digunakan ialah studi dokumen atau sudi pustaka dengan menggunakan metode deskriptif kualitatif. Hasil penelitian menunjukan jika hukum bertransaksi dengan e-money adalah mubah atas dasar kaidah "Al ashlu fil mua'malati al ibahah hatta yadullu ad-daliilu ala tahrimiha", namun kemubahan ini hanya terbatas pada e-money dengan prinsip syariah yang berpedoman pada Fatwa Dewan Syariah Nasional. Adapun e-money kovensional dianggap tidak memenuhi prinsip syariah sebaiknya kita menghindari penggunaannya karena ditakutkan adanya unsur riba, gharar, dan maitsir yang dapat merugikan pihak-pihak dalam e-money tersebut.
\end{abstract}

Kata Kunci: E-Money, Maqashid Syariah Fi Al-Muamalah, Maslahah. 


\section{PENDAHULUAN}

Perkembangan teknologi memberi pengaruh yang cukup besar bagi kehidupan dalam setiap aspek, baik dari aspek sosial, budaya, hukum, maupun ekonomi. Salah satu bentuk perkembangan teknologi dalam aspek ekonomi ialah electectrinoc money. Electectrinoc money atau sering kita sebut dengan e-money merupakan instrument pembayaran non tunai berbasis teknologi berupa data-data digital dalam sistim komputer. Pemanfaatan teknologi digital di Indonesia yang sangat besar tentu memberikan dampak bagi berbagai sektor, salah satunya sektor bisnis atau industri yang kemudian melahirkan perdagangan online atau e-commerce. E-commerce ini membentuk pola perdagangan baru dimasyarakat, dimana masing-masing pihak tidak harus saling bertemu dalam melakukan transaksi jual beli atau pemesanan. Metode pembayaran pun juga mengalami perubahan, dimana pihak pembeli dapat melakukan pembayaran jarak jauh dengan menggunakan sarana e-money.

Penggunaan e-money tentu menjadi alternatif terbaik bagi para pelaku bisnis maupun konsumen sebagai alternatif metode pembayaran. Beberapa faktor yang mempengaruhi tingginya minat masyarakat terhadap penggunaan e-money ini diantaranya faktor kepraktisan serta keamanan bertransaksi menggunakan emoney (S. Utami, 2017). Pada dasarnya penggunaan e-money tidak jauh berbeda dengan penggunaan uang pada umumnya karena keduanya berfungsi sebagai alat pembayaran atas suatu transaksi jual beli. Hanya saja metode pembayaran e-money mengharuskan kepada kita untuk untuk mengisi saldo e-money terlebih dahulu (biasa disebut dengan top-up).

Bagi umat muslim perkembangan teknologi tentu harus sejalan dengan konsepkonsep agama, terlebih dengan segala sesuatu yang berhubugan dengan perkembangan ekonomi kontemporer sepertihalnya e-money. Penggunaan e- money dalam beberapa hal masih menimbulkan keraguan pada sebagian masyarakat awam yang baru mengenalnya. E-money merupakan salah satu bentuk modernisasi Islam dalam bidang keuangan. Penggunann e-money ini tentu tidak lepas dari nilai mata uang yang digunakan. Sehingga adanya e-money tidak menggantikan uang sebagai mata uang yang sah melainkan sebagai alternatif pembayaran yang memberikan kemudahan akses, kenyamanan, serta biaya yang lebih ekonomis. Maka tidak heran jika salah satu bentuk modernisasi tersebut diperbolehkan menurut perspektif hukum syariah berlandaskan dari banyaknya kemashlahatan yang terdapat didalamnya.

Pada dasarnya agama Islam tidak membatasi inovasi dan kreatifitas dalam bermuamalah, hanya saja dalam bermuamalah seyogyanya umat Islam tidak hanya berorientasi pada materi saja, namun juga keberkahan. Adapun modernisasi metode pembayaran berbasis e-money ini tentu harus sejalan dengan prinsip-prinsip agama. Akad yang digunakan dalam e-money juga harus sejalan dengan prinsip akad yang ada, sehingga tidak menimbulkan kebingungan dan ketidak jelasan.

Selain akad, kemaslahatan kedua pihak yang bertransaksi juga merupakan aspek penting yang harus dikedepankan. Kemaslahatan yang dimaksud tentu merupakaan kemaslahatan yang diridhoi Allah SWT, bukan kemaslahatan dalam hal keburukan. Sehingga seluruh pelaku kegiatan ekonomi baik individu, lembaga, maupun instansi harus mampu mewujudkan social welfare baik bagi dirinya maupun bagi lawana usaha serta partner usahanya. Dengan tercapainya social welfare tersebut maka almaslahah al- 'ammah (kemaslahatan umum) juga tercapai (Syufa'at, 2013). Oleh karena itu akad serta segala aktivitas dalam e-money harus sejalan dengan konsep maqashid syariah fi al-muamalah sehingga dapat diketahui konsekuensi hukum yang akan timbul, yang tentunya tidak jauh dari hukum 
sah-batal, boleh-tidak boleh, wajib-haram, berhak-tidak berhak, dan sebagainya.

\section{LITERATURE REVIEW}

Berikut beberapa penelitiaan yang telah dilaporkan atau ditulis oleh peneliti terdahulu yang berkaitan dengan e-money yaitu, pertama Choiril Anam dalam "E-money (Uang Elektronik) Dalam Perspektif Hukum Syari'ah". E-money merupakan sarana pembayaran yang dikeluarkan atas dasar nominal uang yang telah disetorkan oleh pemegang kepada penerbit e-money. Uang tersebut akan disimpan dalam suatu sistim elektronik penerbit, yang kemudian dapat digunakan oleh pemegang e-money sebagai alat pembayaran kepada pedagang. Metode penelitian yang digunakan adalah metode kualitatif dengan pendekatan kualitatif normatif. Dari penelitian tersebut diketahui jika penggunaan e-money sebagai media pembayaran berpengaruh positif terhadap tingkat konsumsi masyarakat. Hal ini dikarenakan e-money memberikan fasilitas yang cukup mudah dan efisien dalam bertansaksi, sehingga mendorong daya beli masyarakat semakin tinggi yang pada akhirnya berpotensi mendorong aktivitas ekonomi pada sektor riil.

Kedua, oleh Muhammad Ridwan Firdaus dalam "E-Money dalam Perspektif Hukum Ekonomi Syariah". E-money merupakan bentuk baru dari uang yang senantiasa berubah seiring dengan perkembangan zaman. Islam tidak memberikan larangan bagi umatnya untuk mencari keuntungan yang diperoleh dari jasa keuangan elektronik. karena yang dilarang adalah upaya membeli uang dengan uang. Berbeda dengan transaksi jual beli uang, dalam e-money ini pengguna memberikan ujrah kepada penerbit atas jesa kemudahan transaksi yang ditawarkan. Sehingga penyedia jasa e-money mendapatkan keuntungan dari jasa yang mereka sediakan, dan pengguna mendapatkan manfaat atas penyediaan layanan jasa e-money. E-money merupakana sesuatu yang dianggap mubah, karena pada dasarnya segala sesuatu dalam kegiatan muamalah adalah boleh, asal tidak keluar dari kebenaran syara' dan undangundang.

Ketiga, oleh M Rizky Wady Abdulfattah dan Rachmat Rizky Kurniawan dalam "Uang Elektronik Dalam Perspektif Islam". Banyak manfaat yang didapatkan dari sitem pembayaran melalui e-money seperti lebih aman, efisisien, cepat, dan mudah. Uang elektronis secara umum telah memenuhi prinsip maqashid syariah dengan dengan terpenuhinyaa prinsip memelihara harta dan kemaslahatan. Namun jenis $e$ money unregistered dianggap belum sesuai dengan konsep maqashid syariah karena emoney ini dianggap dapat menimbulkan kemudharatan karena tidak dilengkapi dengan PIN, sehingga menimbulkan peluang terjadinya tindak pencurian.

Dari ketiga penelitian yang telah disebutakan diatas, penelitian pertama fokus pada aspek maslahah serta faktor-faktor yang mempengaruhi masyarakat dalam pengguaan e-money. Adapun penelitian kedua membahas tentang e-money perspektif ekonomi syariah secara umum. Sedangkan penelitian ketiga fokus pada unsur-unsur kemaslahatan yang terdapat pada e-money.

Dari ketiga penelitian tersebut penelitian ini menjadi penting untuk dijadikan pembahasan terkait Maqashid Syariah Fi al-Muamalah terhadap e-money. Penelitian ini akan fokus pada akad apa saja yang terdapat pada e-money, dan bagaimana konsep maqashid syariah fi al-muamalah yang terdapat pada e-money yang dapat menimbulkan konsekuensi hukum tersendiri di mana konsekuensi yang timbul tidak jauh dari pakem sah-batal, boleh-tidak boleh, wajib-haram, berhak-tidak berhak, dan sebagainya.

\section{METODE PENELITIAN}

Jenis penelitian ini merupakan penelitian hukum normatif. Penelitian hukum normatif disebut juga dengan penelitian kepustakaan, yang dalam hal ini peneliti melakukan 
pengumpulan bahan-bahan kepustakaan, seperti buku maupun penelitian-penelitian lainnya yang berhubungan dengan e-money serta teori maupun konsep maqashid syariah fi al-muamalah (Ochtoria dan A'an Efendi, 2014).

Pendekatan penelitian yang digunakan ialah pendekatan kualitatif normatif, dimana dalam menjawab rumusan masalah dilakukan dengan cara meneliti serta mendeskripsikan bahan pustaka yang telah dikumpulkan, kemudian disusun, dijelaskan, diintrerpretasikaan, serta ditarik kesimpulan dalam bentuk catatan atau tulisan yang bersifat deskriptif (Soekanto \& Sri Mamudji, 2009).

Teknik pengumpulan bahan hukum pada penelitian hukum normatif khususnya pada data skunder dapat dibatasi pada penggunaan studi dokumen atau pustaka saja Studi dokumen merupakan metode pengumpulan bahan hukum dengan cara mengidentifikasi karakteristik pesan atau maksud dari suatu bahan hukum secara objektif dan sistematis melalui pengumpulan data tertulis berupa dokumen maupun literatur-literaur lain yang berkaitan dengan penelitian (Soekanto. 2015). Dalam penelitian ini, penulis melakukan studi dikumen dari bahan-bahan kepustakaan, seperti buku maupun penelitian-penelitian lainnya yang berhubungan dengan e-money serta teori maupun konsep maqashid syariah fi almuamalah.

Dalam memaparkan data penelitian ini menggunakan metode deskriptif kualitatif. Jenis penelitian ini pada umumnya memang dgunakan untuk penelitian fenomena sosial, seperti halnya terkait dengan perkembangan penggunaan $e$-money masa kini. Langkah penggunaan analisis deskriptif kualitatif dapat melibatkan tiga tahapan yaitu tahap pertama, reduksi data, yaitu menekankan pada pemokusan data yang akan diambil oleh peneliti; kedua, data display yaitu penyajian data dalam bentuk uraian singkat, bagan, hubungan antar kategori. Tujuannya adalah untuk memudahkan memahami apa yang terjadi dan merencanakan tahapan selajutnya berdasarkan apa yang telah dipahami tersebut; ketiga, penarikan kesimpulan (Yuliani, 2018).

Berdasarkan paparan tersebut, dapat diketahui bahwa proses analisis deskriptif kualitatif diperlukan deskripsi data yang telah dikumpulkan yang memberikan gambaran umum objek penelitian (Hanitijo, 1994). Kemudian disusun, dijelaskan, dianalisa dan diinterpretasikan, serta ditarik kesimpulan dalam bentuk catatan atau tulisan yang bersifat deskriptif (Andari, 2004) sesuai dengan rumusan masalah yang telah dirumuskan sebelumnya.

\section{KONSEP DASAR \\ Pengertian E-Money}

Menurut Pasal 1 ayat 3 Peraturan Bank Indonesia Nomor: 11/12/PBI/2009 Tentang Uang Elektronik (Electronic Money), e-money atau yang sering disebut dengan digital currency, digital money, digital cash, electronic cash, ataupun electronic currency merupakan alat pembayaran dalam bentuk elektonik yang digunakan sebagai alat bayar oleh pemegang e-money kepada pedagang yang bukan merupakan penerbit uang elektronik, yang nilainya ditentukan atas dasar uang yang disetor oleh pemegang terlebih dahulu kepada penerbit, dimana nilai uang tersebut tersimpan secara elektronik dalam suatu media seperti server atau chip, dan nilai uang tersebut bukan merupakan simpanan sebagaimana simpanan pada perbankan.

Dari pengertian yang yang telah dijelaskan diatas dapat kita pahami beberapa unsur yang harus ada dalam e-money yaitu:

1) Penerbitan e-money didasarkan atas nominal uang yang telah disetorkan terlebih dahulu oleh pengguna;

2) Adanya sistem penyimpanan elektronik seperti dalam bentuk server atau chip yang berfungsi untuk menyimpan nilai uang yang telah disetor; 
3) E-money digunakan sebagai alat pembayaran kepada pedagang yang bukan merupakan penerbit dari emoney tersebut;

4) Uang yang telah disetor oleh pengguna e-money mtidak dapat disamakan dengan simpanan pada perbankan sebagaimana yang telah diatur dalam undang-undang perbankan.

\section{Manfaat E-Money}

Berikut ini merupakan beberapa manfaat emoney, diantaranya :

1) Penggunaan dalam pembayaran sangat mudah, cukup tempelkan kartu maupun transaksi secara mobile untuk bertransaksi tanpa repot akan uang kembalian.

2) Dapat meminimalkan penggunaan uang kertas sehingga memimalisir kerusakan fisik uang yang beredar, meminimalisir peredaran uang palsu, dan menimalisir resiko pencurian.

3) Sangat baik untuk pembayaran massal yang bernilai kecil namun frekuensinya tinggi seperti pembayaran jalan tol, parkir, transportasi.

\section{Jenis-Jenis E-Money}

Jenis e-money dibedakan menjadi beberapa kategori. Berdasarkan media penyimpanannya e-money dibagi menjadi dua, yaitu :

1) E-money yang nilai uangnya selain dicatat oleh penerbit melalui sistimnya juga dicatat oleh pengguna atau pemegangnya, pencatatan oleh pemganag dapat berupa chip yang tersimpan pada kartu, stiker, atau harddisk yang terdapat pada personal computer milik pemegang. Dengan sistem pencatatan seperti ini, maka transaksi pembayaran dengan menggunakan uang elektronik dapat dilakukan secara off-line dengan mengurangi secara langsung nilai uang.

2) Uang elektronik yang nilai uang hanya dicatat pada media elektronik yang dikelola oleh penerbit e-money. Dalam hal ini pemegang diberi hak akses oleh penerbit terhadap penggunaan nilai uang elektronik tersebut. Dengan sistem pencatatan seperti ini, maka transaksi pembayaran dengan menggunakan uang elektronik ini hanya dapat dilakukan secara on-line dimana nilai uang elektronik yang tercatat pada media elektronik yang dikelola Penerbit akan berkurang secara langsung (Anam, 2018).

Berdasarkan masa berlakunya emoney atau uang elektronik dibedakan menjadi dua:

1) Uang elektronik reloadable yang dapat dilakukan isi ulang (top up) dan apabila masa berlakunya sudah habis dan atau nilai uang elektroniknya sudah habis terpakai, maka media uang elektronik tersebut dapat digunakan kembali untuk di lakukan pengisian ulang.

2) Uang elektronik yang tidak dapat dilakukan isi ulang (disposable), maka apabila masa berlakunya sudah habis dan/atau nilai uang elektroniknya sudah habis terpakai, maka media uang elektronik tersebut tidak dapat digunakan kembali untuk dilakukan pengisian ulang.

Berdasarkan jangkauan penggunaanya uang elektronik dibedakan menjadi dua:

1) Single-purpose yaitu uang elektronik yang hanya dapat digunakan untuk satu jenis transaksi saja, seperti pembayaran kewajiban yang timbul akibat adanya suatu transaksi ekonomi;

2) Multi-purpose merupakan uang elektroni yang dapat digunakan pada berbagai jenis transaksi ekonomi. 
Berdasarkan tercatat atau tidaknya identitas pemegang/pengguna uang elektronik dibedakan menjadi dua;

1) Uang elektronik regitered merupakan uang elektronik yang identitas penggunanya sudah tercatat dan terdaftar;

2) Unregistered merupakan uang elektroni yang identitas penggunanya belum tercatat dan terdaftar. Adapun pada uang elektronik unregistered batas maksimal nilai uangnya sebesar satu juta rupiah (Muamar \& Ari Salman Alparisi, 2017).

\section{Maqashid Syariah Fi al-Muamalah}

Secara bahasa, maqasid al-shariah berasal dari dua kata yaitu maqasid dan shariah. Maqasid merupakan bentuk plural dari kata maqasid yang berarti kesengajaan atau tujuan. Sedangkan kata syariah, berasal dari kata al-shariah dan sinonim dengan kata alshir'ah (Syufa'at, 2013). Menurut pengertian istilah Mahmud Syalthut dalam bukunya yang sangat terkenal "al-Islam Akidah wa Syariah", bahwa syariah adalah nama dari sebuah sistem dan hukum yang diberikan oleh Allah swt, atau ditetapkan oleh Allah dasar-dasarnya dan mewajibkan setiap muslim melaksanakannya, untuk menata diri mereka dengan dasar-dasarnya terkait hubungan mereka dengan Allah swt dan dengan sesama manusia. Secara terminologis, Wahbah al-Zuhaili mendefinisikan maqashid syariah sebagai nilai, sasaran, serta maksud yang tersirat dalam suatu syara' yang dipandang sebagai tujuan dan rahasia syariah yang ditetapkan oleh al-Syari', baik dalam sebagian besar atau segenap ketentuan hukumnya (Ishak, 2013).

Penjelasan maqashid syariah dalam kitab al-Muwafaqat dapat dilihat dari dua aspek yaitu maksud Syari' (qashdu al-syari') serta maksud mukallaf atau (qahsdu almukallaf fi al-taklif). Qashdu al-Syari' merupakan maksud al-Syari' dalam menciptakan syariat bagi umat manusia.
Allah selaku menciptakan syariat bagi umat manusia tidak lain adalah untuk menjaga kemaslahatan manusia, dan menjauhkannya dari kemudharatan serta kemafsadatan dunia dan akhirat. Maqashid qashdu al-Syari' dibedakan menjadi tiga bagian yaitu dlaruriyat, hajiyat, tahsiniyat. Pertama, maqshid dlaruriyat yaitu mqashid yang harus ada dalam kehidupan manusia, sehingga dengan tidak terpenuhinya maqashid ini akan berdampak pada kemaslahatan hidup umat manusia, dan dikhawatirkan mandatangkan kemafsadatan yang dilihat dari sejauh mana kerusakan yang timbul apabila dlaruriyat tersebut hilang atau tidak ada (Fauzia dan Abdul Kadir Riyadi, 2014).

Terdapat lima Maqashid aldlaruriyat yang wajib ada dalam kehidupan manusia yaitu: menjaga agama (hifz al-din), menjaga jiwa (hifz al-nafs), menjaga akal (hifz al-'aql), menjaga harta (hifz al-mal), menjaga keturunan (hifz al-nasl). Kedua, Maqashid al-hajiyat disebut juga sebagai kebutuhan sekunder, dimana apabila kebutuhn ini terpenuhi maka dapat menghilangaka kemafsadatan dari kehidupan mukallaf. Ketiga, maqashid tahsiniyat, maqashid ini bertujuan untuk menyempurnakan kedua maqashid sebelumnya seperti akhlak yang mulia, kebiasaan yang baik, dan kesempuraan adat (Toriquddin, 2014).

Terdapat dua cara yang dapat ditempuh untuk menjaga kelima maqashid tersebut yaitu:

1) Min haytsu al-wujud yaitu menjalankan segala kegiatan ibadah maupun muamalah yang dapat mendatangkan kemaslahatan dalam hidup

2) Min haytsu al-adam yaitu menghindari segala aktivitas yang merusak amalan baik yang telah dilakukan yang dapat merusak kemaslahatannya dan mendatangkan mafsadat (kasdi, 2014). 
Sedangkan maksud mukallaf (qahsdu al-mukallaf fi al-taklif) berkaitan dengan tindakan mukallaf dalam melakukan segala perbuatan. Setiap maksud perbuatan yang dilakukan mukallaf harus sejalan dengan maksud Allah menurunkan syariat-Nya kepada umat manusia, yaitu untuk menjaga kemaslahatan manusia didunia dan mencapai kemaslahatan di akhirat.

\section{PEMBAHASAN DAN DISKUSI}

\section{Akad-Akad Dalam e-Money}

Sepertihalnya perbankan, tidak semua $e$ money menerapkan prinsip syariah dalam setiap transaksinya. E-Money yang menerapkan prinsip syariah harus berpedoman pada Fatwa Dewan Syariah Nasional sebagaimana yang telah diamanatkan oleh Undang-Undang, hal ini berfungsi untuk menjamin kehalalan bertransaksi menggunakan e-money. Adapun beberapa ketentuan terkait e-money yang sejalan dengan prinsip syariah dapat kita lihat dari berbagai aspek seperti halnya objek transaksi yang mengharuskan objek yang halal, penempatan dana penerbit pada bank syariah, serta penjaminan atas nominal uang yang ada di penerbit jika kartu yang digunakan sebagai media uang elektronik hilang, dll.

Akad-akad yang digunakan diantara para pihak yang bersangkutan pun juga harus sesuai dengan prinsip syariah. Sebelum membahas lebih jauh terkait akad apa saja yang digunakan perlu kita ketahui terlebih dahulu pihak-pihak yang terlibat dalam transaksi e-money ini: pertama ialah penertbit yang merupakan pihak yang menerbitkan uang elektronik atau e-money; kedua pemegang e-money yaitu pihak yang menggunakan uang elektronik sebagai sarana pembayaran atau penagihan; ketiga ialah pihak-pihak lain dalam penyelenggaraan uang elektronik yaitu pihak prinsipal, acquirer, merchant atau pedagang, penyelenggara kliring atau penyelenggara penyelesaian akhir.
Para pihak yang bertransaksi menggunakan e-money dihubungkan dengan akad-akad syariah yang berpedoman pada Fatwa Dewan Syariah Nasional Majelis Ulama Indonesia tentang uang elektronik syariah. Pertama, antara penerbit dan pengguna/pemegang e-money diberlakukan akad wadiah (titipan) atau akad qardh (hutang). Akad wadiah berlaku dengan ketentuan nominal uang elektronik yang bersifat titipan dapat diambil dan digunakan oleh pemegang kartu kapan saja ia inginkan, sedangkan penerbit tidak boleh menggunakan titipan tersebut tanpa izin pemegang kartu, namun apabila niminal uang elektronik yang dititipkan tersebut digunakan oleh penerbit atas izin pemegang kartu maka akad wadiah akan berubah menajadi akad qardh. Kedua antara penerbit dengan para pihak penyelenggara elektronik money yaitu pihak prinsipal, acquirer, merchant atau pedagang, penyelenggara kliring atau penyelenggara penyelesaian akhir berlaku ketentuan akad ijarah, akad jualah, dan akad wakalah bi al-ujrah.

\section{E-Money dalam Perspektif Maqashid Syairah Fi al-Muamalah}

Syariat yang telah ditetapkan oleh Allah SWT tentu memiliki maksud dan tujuannya tersendiri. Maksud dan tujuan ditetpkannya syariat ini dapat diketahui melaui konsep maqashid syariah yang pada akhirnya segala syariat yang di turunkan Allah adalah untuk menjaga kemaslahatan umat manusia dan menjauhkannya dari kemudharatan (Toriquddin, 2014). Sehingga untuk menjaga tujuan syariat tersebut sudah selayaknya umat manusia turut menjaga kemaslahatan yang diciptakan Allah SWT dalam setiap perbuatannya baik dalam hal ibadah maupun mamalah.

Maqashid syariah yang dijelaskan oleh Imam al-Syatibi dalam kitabnya alMuwafaqat dibagi kedalam tiga bagian yaitu dlaruriyat, hajiyat, dan tahsiniyat. Teori maqshid syariah yang dijelaskan tersebut tidak terbatas pada aspek ibadah saja 
melainkan juga mencakup aspek selain ibadah (ghairu ubudduyah) seperti bidang muamalah serta praanata sosial lainnya. Dalam bidang mamalah maqashid syariah dapat dijadikan sebagai metode pendekatan dalam berijtihad. Karena maqashid syariah mengandung maksud penetapan hukum Syar'i yang hanya dapat diketahui melalui akal pikiran dengan metode ijtihad yang penuh dengan kehati-hatian, sehingga tidak bertentangan dengan syariat serta terhindar dari keinginan hawa nafsu.

Implementasi Maqashid syariah tentu tidak lepas dari prinsip maslahah yang selalu mengutamakan kemaslahatan sebagai tujuan utama. Maslahat merupakan prinsip dalam ekonomi syraiah dimana dalam suatu kegiatan muamalah harus selalu mengupayakan kemaslahatan serta kemanfaatan kedua pihak, serta menghindari segala hal yang mendatangkan kemafsadatan yang dapat merusak akad, transaksi dan kegiatan muamalah lainnya yang telah mereka lakukan (Soemitra, 2019). Sehingga untuk mewujudkan kemaslahatan ini seluruh pelaku ekonomi baik individu dan seluruh pelaku usaha lainnya harus mampu mewujudkan social welfare baik bagi dirinya, lawan usaha, serta partner usahanya. Dengan tercapainya social welfare tersebut maka al-maslahah al- 'ammah (kemaslahatan umum) akan ikut tercapai (Syufa'at, 2013).

Perkembangan dan perubahan zaman yang begitu cepat memang tidak mungkin untuk hindari, namun Islam juga tidak akan pernah usang oleh persoalan-persoalan modern yang selalu datang dan memerlukan jawaban. Sejalan dengan hal tersebut maqashid syariah memberikan landasan ijtihad atas segala bentuk kegiatan muamalah modern yang sejalan dengan nilai-nilai Islam. Maqashid syariah akan terus berkembang dan tidak akan pernah tertinggal dengan perkembangan zaman serta kecanggihan teknologi yang semakin maju. Maqashid syariah fi al-uamalah yang mengedepankan kemaslahatan umum (almaslahah al-'ammah) selalu memberikan jawaban dari keraguan atas kegiatan muamalah baru yang terus berkembang, dengan memperhaatikan kemaslahatan umum yang sejalan dengan qashdu al-syari'.

$$
\text { E-money yang merupakan }
$$

modernisasi dari metode pembayaran yang dipadang boleh atau mubah, hal ini sejalan dengan kaidah fiqih yang berbunyi:

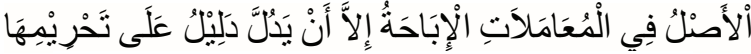 \\ "Pada dasarnya, semua bentuk muamalah boleh dilakukan kecuali ada dalil yang mengharamkannya."}

Kaidah tersebut membolehkan segala bentuk kegiatan muamalah selama tidak ada dalil yang menfatwakan keharamannya, sehingga e-money merupakan instrumen pembayaran modern yang diperbolehkan secara syara'. Namun, kebolehan e-money ini terbatas pada e-money syariah saja, sedang e-money dengan sisitim konvensional dipandang sebagai kegiatan muamalah yang tidak memenuhi prinsip syariah yang telah ditetapkan dalam fatwa DSN-MUI tentang uang elektronik, sehingga sebaiknya kita menghindari penggunaan e-money konvensional karena ditakutkan adanya unsur riba, gharar, dan maitsir yang dapat merugikan pihak-pihak dalam e-money tersebut. Mengat salah satu kaidah fiqih yang berbunyi:

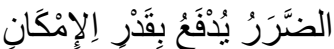 \\ "Dharar (bahaya/kerugian) harus \\ dicegah sebisa mungkin"}

Wajib hukumnya bagi kita mencegah kemadharatan semampu dan semaksimal mungkin, baik sebelum kemudaratan itu terjadi maupun sesudahnya, oleh karena itu harus ada usaha bagi kita untuk menghindarinya (Arfan, 2017). Menghindarkan diri dari segala hal yang membahayakan dan membawa kerugian merupakan upaya untuk menjaga kehalalan dan kesucian harta dan terjauh dari riba, gharar, maupun maitsir. Riba adalah sesuatu yang mutlak keharamannya, hal ini sudah dituliskan dalam QS al-Baqarah ayat 275 yang berbunyi: 
.... “...Padahal Allah telah menghalalkan jual beli dan mengharamkan riba..."

Ayat tersebut memberikan penjelasan kepada kita segala sesuatu yang berhubungan dengan riba adalah haram hukumnya. Sehingga untuk menghindari hal tersebut dalm bertransaksi menggunakan e-money seyogyanya kita menggunakan e-money syariah yang berpedoman pada fatwa Dewan Syariah Nasional Majelis Ulama' Indonesia.

\section{KESIMPULAN}

Islam tidak membatasi inovasi dan kreatifitas dalam bermuamalah, namun ada ketegasan dalam batasan-batasan yang tidak boleh dilakukan. Penggunaan e-money sebagai alat pembayaran baru tentu di bolehkan dan mubah hukumnya. Namun mubahnya emoney ini sebatas pada e-money dengan prinsip syariah yang berpedoman pada Fatwa Dewan Syariah Nasional. Adapun e-money kovensional dianggap tidak memenuhi prinsip syariah sebaiknya kita menghindari penggunaannya karena ditakutkan adanya unsur riba, gharar, dan maitsir yang dapat merugikan pihak-pihak dalam e-money tersebut.

Penelitian ini diharapkan menjadi rujukan bagi pihak pengguna dalam kegiatan muamalahnya dengan e-money, serta menjadi rujukan pula bagi penerbit e-money dalam pengembangan serta konsistensi prinsip syariah yang dijalankan.

\section{DAFTAR PUSTAKA}

Anam, Choiril. (2018). E-money (Uang Elektronik) Dalam Perspektif Hukum Syari'ah. Qawãnïn, 2(1), 100 DOI:10.30762/q.v2i1.1049

Andari, Durri. (2004). Metodologi Penelitian. Tangerang Selatan: Universitas Terbuka.

Arfan, Abbas. (2017). 99 Kaidah Fiqih Muamalah Kulliah. Malang: UIN Maliki Press.

Fauzia, Ika Yunia dan Abdul Kadir Riyadi. (2014). Prinsip Dasar Ekonomi Islam
Perspektif Maqashi al-Syariah.

Rawamangun: Kencana.

Hanitijo, Rony. (1994). Metode Penelitian Hukum dan Jurimeter. Jakarta: Ghalis. Ishak, Khodijah. (2013). Maqosid Syari'ah Sebagai Dasar Sistem Ekonomi Berkeadilan, Iqtishaduna, 2(2). 594 https://ejournal.stiesyariahbengkalis.ac .id/index.php/iqtishaduna/article/view/ 38

Kasdi, Abdurrahman. (2014). Maqashid Syari'ah Perspektif Pemikiran Imam Syatibi dalam Kitab Al-Muwafaqat. Yudisia, 5(1). 57 DOI: http://dx.doi.org/ 10.21043/yudisia.v5i1.693

Muamar, Afif dan Ari Salman Alparisi, ((2017). Electronic Money (E-Money) dalam Perspektif Maqashid Syariah", Journal of Islamic Economics Lariba, 3(20.75-84https://journal.uii.ac.id/ JIELariba/article/view/9657

Ochtoria, Dyah dan A'an Efendi. (2014). Penelitian Hukum (Legal Research). Jakarta: Sinar Grafika.

Peraturan Bank Indonesia Nomor: 11/12/PBI/2009 Tentang Uang Elektronik (Electronic Money).

Soekanto, Soerjono dan Sri Mamudji. (2009). Penelitian Hukum Normatif Suatu Tinjauan Singkat. Cet. 11, Jakarta: PT. Raja Grafindo Persada.

Soekanto, Soerjono. (2015). Pengantar Penelitian Hukum. Jakarta: UI-Press.

Soemitra, Andri. (2019). Hukum Ekonomi Syariah dan Fiqh Muamalah di Lembaga Keuangan dan Bisnis Kontemporer. Rawamangun: Prenadamedia Group.

Syufa'at. (2013). Implememtasi Maqashid Al-Syari'ah Dalam Hukum Ekonomi Islam. al-Ahkam. 23(2).146-151.DOI:

10.21580/ahkam.2013.23.2.20

Toriquddin, Moh. (2014). Teori Maqashid Syari'ah Perspektif Al-Syatibi, de Jure, Jurnal Syariah dan Hukum.6(1) 35. DOI: https://doi.org/10.18860/jfsh.v6i1.3190 
Utami S. (2017). Fakto-Faktor Yang Mempengaruhi Minat Penggunaan EMoney (Studi pada Mahasiswa STIE Ahmad Dahlan Jakarta). BALANCE : Economic, Business, Management, and Accounting Journal, 14(2).

DOI: http://dx.doi.org/10.30651/blc.v1 4i02.1265

Yuliani, Wiwin. (2018). Metode Penelitian Deskriptif Kualitatif Dalam Perspektif Bimbingan dan Konseling. Jurnal QUANTA, 2(2). 83-91. DOI: 10.22460/q.v2i1p21-30.642. 